\title{
SPATIO-TEMPORAL VARIABILITY MONITORING OF THE FLOODS IN THE CENTER-WEST OF THE BUENOS AIRES PROVINCE (ARGENTINA) USING REMOTE SENSING TECHNIQUES. THE ROLE OF SAND DUNES
}

\author{
FELIX I. CONTRERAS ${ }^{1,2 *}$, GIAN M. MAVO MANSTRETTA ${ }^{3}$, \\ MARIA C. PICCOLO ${ }^{3,4}$, GERARDO M.E. PERILLO ${ }^{3,5}$ \\ ${ }^{1}$ Centro de Ecología Aplicada del Litoral (CONICET - UNNE), \\ Ruta $5 \mathrm{~km} \mathrm{2,5} \mathrm{s/n,} 3400$ Corrientes, Argentina. \\ ${ }^{2}$ Departamento de Agrimensura, Universidad Nacional del Nordeste, \\ Avda. Libertad 5460, 3400 Corrientes, Argentina. \\ ${ }^{3}$ Instituto Argentino de Oceanografía (CONICET-UNS), \\ Camino a la Carrindanga km 7, 8000 Bahía Blanca, Argentina. \\ ${ }^{4}$ Departamento de Geografía y Turismo, Universidad Nacional del Sur, \\ 12 de octubre y San Juan, 8000 Bahía Blanca, Argentina. \\ ${ }^{5}$ Departamento de Geología, Universidad Nacional del Sur, \\ Avda. Alem 1253, 8000 Bahía Blanca, Argentina.
}

\begin{abstract}
Floods are recurring events in Buenos Aires Province, mainly caused by high-intensity precipitation, and in some cases, they persist for long periods. The objective of this study is to analyze how the topography of the central-western portion of Buenos Aires Province determines the occurrence and the extent of floods. The presence of shallow lakes characterizes the area which is controlled by the topography. LANDSAT 5 and 8 images corresponding to periods of drought and flooding in the area were compared with topographic profiles and digital elevation models generated from SRTM $3 \mathrm{arc} / \mathrm{sec}$ data. The results showed that in those areas where there are aligned dunes, and after significant storm drain engineering works, during the wet periods, the lakes, their overflows, and the subsequent runoff to the east of Buenos Aires Province flow freely, limiting the flood areas. Due to this topography, the lakes became a more permanent feature of the landscape, even during extreme drought events. In contrast, in those areas where parabolic dunes predominate, the landscape is more affected by droughts and floods. During drought events, we observed a small number of shallow lakes, and during strong storms with high-intensity rainfall, the number of lakes increases and large flooded areas generate damage to agricultural fields and neighboring cities, either due to natural causes or improvised and illegal storm drains. Early warning of flood risks and a systematic territorial ordaining would be the key to the management of the area.
\end{abstract}

\section{Seguimiento de la variabilidad espacio-temporal de las inundaciones en el centro-oeste de la Provincia de Buenos Aires (Argentina) mediante técnicas de teledetección. El papel de las dunas de arena}

RESUMEN. Las inundaciones son eventos recurrentes en la provincia de Buenos Aires causados principalmente por precipitaciones de gran intensidad. En algunos casos, persisten durante prolongados periodos de tiempo. El objetivo de este trabajo es analizar cómo la topografía del centro-oeste de la provincia de Buenos Aires ha determinado la ocurrencia y extensión de las inundaciones. El área se caracterizada por la presencia de lagunas 
que son controladas por la topografía. Imágenes de satélite LANDSAT 5 y 8 correspondientes a períodos de sequía e inundación fueron comparadas con perfiles topográficos y modelos de elevación digital generados a partir de datos SRTM de $3 \mathrm{arc} / \mathrm{seg}$. Los resultados demostraron que, en aquellas zonas donde existen dunas alineadas, con importantes obras de ingeniería (desagües pluviales), las lagunas, sus desbordamientos y la posterior escorrentía se realiza de manera encauzada hacia el este de la provincia de Buenos Aires, limitando las áreas de inundación. Debido a esta disposición topográfica, los lagos tuvieron un mayor período de permanencia, incluso en eventos extremos de sequía. Por otro lado, en aquellos lugares donde predominan las dunas parabólicas, el paisaje se ve más afectado por las sequías e inundaciones. Durante los eventos de sequía se observa un menor número lagos poco profundos, y durante tormentas fuertes, con lluvias de alta intensidad, el número de lagos aumenta y las áreas inundadas se extienden, generando daños a los campos agrícolas y a las ciudades vecinas, ya sea por causas naturales o por drenajes improvisados e ilegales. La alerta temprana de los riesgos de inundación y una ordenación territorial serían la clave para la gestión de la zona.

Key words: Dunes, topography, floods, shallow lakes, runoff.

Palabras clave: Dunas, topografía, inundaciones, lagunas, escorrentía.

Received: 7 January 2020

Accepted: 25 May 2020

* Corresponding author: Félix Ignacio Contreras, Centro de Ecología Aplicada (CONICET-Universidad Nacional del Nordeste), Ruta 5 km 2.5 s/n, 3400 Corrientes, Argentina. E-mail: ignaciocontreras@conicet.gov.ar

\section{Introduction}

The manifestation of droughts and floods in the distribution and extension of water bodies in a certain region depends on a series of factors. In one hand, several studies had shown that the precipitation, either by its scarcity or by its excesses, constitutes one of the main variable that determine the manifestation of floods and droughts (Quirós, 2002; Kwak and Kondoh, 2008; Ferrelli and Aliaga, 2016). On the other hand, the geology and its related processes, the terrain slope, the vegetation, the topography and the soil types (Scarpati et al., 2008; Frot and Wesemael, 2009) are key factors in the landscape evolution (Kasprak et al., 2019). Although such factors should be considered when studying floods and droughts (Tripaldi et al., 2018); they are seldom discussed. Even more, for aeolian environment, there is a lack of information about the role of the topography and the aeolian morphologies associated, mainly dunes, in the development of the surface drainage and water accumulations process.

The modern dune systems (Perillo, 2001) constitute one of the most prominent morphologies created by sedimentary deposits driven by wind (Blumberg, 2006). These systems have complex arrangements of geomorphic elements, including the dunes and interdune areas. These areas occur on a wide range of scales, are characterized by a variety of morphologies (Al-Masrahy and Mountney, 2013), and contain important paleoenvironmental and paleoclimatic information (Ivester and Leigh, 2003, Tripaldi and Zarate, 2016). The dune system of Buenos Aires Province (Argentina) in the study area have mainly longitudinal and parabolic dunes. The longitudinal dunes are arranged in parallel ridges, with a well-defined wavelength when they are large (Courrech du Pont, 2015). Meanwhile, parabolic dunes typically have a U- or V-shaped lobe with two trailing arms pointing upwind encompassing a deflation basin (Yan and Baas, 2017). They are known to be genetically associated with an adequate sand supply (Yan and Baas, 2017), moderate to high vegetation cover (Tsoar, 2001; Ivester and Leigh, 2003; Pye and Tsoar, 2009), unidirectional wind (Ivester and Leigh, 2003) and are mostly found in humid and cold areas (Tsoar, 2001). As in other areas worldwide, these dunes are mostly inactive and 
stabilized by vegetation (Ivester and Leigh, 2003), but also deeply disturbed by cattle grazing and agriculture (Zarate and Tripaldi, 2012; Contreras et al, 2018; Tripaldi et al., 2018).

There are shallow lakes between the dunes that intervene in the hydrological characteristics. Water coming from both rainfall and groundwater in low runoff areas and from what is stored in the dunes recharges these shallow lakes (Yang et al., 2003). In the case of the Pampean region, water from rainfall is not always able to infiltrate because the water table is very close to the surface and only minor amounts of floodwaters percolate through the dune field; so, this water would be transported to form shallow lakes (Forte Lay et al., 2008). Topography, climatic regime, drainage, soils and anthropogenic activities explain the structure and functioning of these lakes (Ferrelli and Aliaga, 2016).

There may be considerable portions of known aeolian systems that remain under-sampled, or systems that remain undocumented (Barrineau et al., 2019); but thanks to the studies of dunes using remote sensing (Blumberg, 2006; White et al., 2015; Telfer et al., 2015; Saadouda et al., 2018; Contreras et al, 2018; Tripaldi et al., 2018), significant advances in the knowledge of their evolution and morphological dynamics have been made. Morphometric analysis is cost-effective (Möller et al., 2008; Mashimbye et al., 2014) and is an established technique for determining the geomorphology of aeolian environments, providing relevant information about processes and controls of dune formation (White et al., 2015). Digital elevation models (DEM), as those derived from Shuttle Radar Topographic Mission (SRTM) data have also been used to determine the heights of dunes and delineate possible flood areas depending on the geomorphological characteristics of these sites (Blumberg, 2006; Bubenzer and Bolten, 2008; Ho et al., 2010; Tripaldi et al., 2018). The recent increase in the availability of highresolution remote sensing data offers important information for the study of aeolian environments (Telfer et al., 2015).

During recent decades, several hydrological events in the Pampean region have been studied due to their effects on agricultural production and soil cover, and their impact on the population and its access to drinking water (Sierra et al., 1994; Scarpati et al., 2008). During the 1949-50, 1962-63, and 1988-89 harvests seasons, severe droughts reduced national production of grains by more than $30 \%$, while during the 1985-1987 and 2001-2002 periods, successive floods in the area made agricultural tasks difficult if not impossible in some sectors.

The west-center of Buenos Aires Province is characterized by cycles of floods and droughts (Sosnovsky and Quirós, 2006; Labraga et al., 2011). In general terms, landform characteristics give information on flow characteristics, such as direction, depth, and behaviour (Carrivick and Rushmer, 2006). In this case, the flat topography and low slopes cause these events to be enhanced due to the low water retention capacity in dry years and limited expulsion capacity of local water excesses in wet periods. In this last scenario, water can be preserved both in the sediments, as it happens in the landscape (McLaren et al, 2009) for longer periods. The lakes located in the west-center of Buenos Aires Province were referred by Frengüelli (1956) as basins originated by aeolian excavation. However, in this region, most of the lakes and creeks are relict basins, whose waters occupy the remains of ancient river channels barely discernible today in the field (Dangavs, 2005). In the last fifty years, the succession of severe meteorological droughts and significant flood periods (Labraga et al., 2011) have not only affected economic activities but also the dynamics of the water bodies and, with it, the biodiversity and land cover of the Pampean region (Quirós et al., 2002; Taboada et al., 2009; Ferrelli, 2012).

Floods not only alter landscapes over different space-time scales but also provide sudden and abrupt inputs of water and sediment (Carrivick and Rushmer, 2006). Floods are also related to changes in social, economic and land use conditions (Kwak and Kondoh, 2008). The use of efficient climate forecasts and knowledge about the repetition of extreme events are the basis for planning the management of water resources (Labraga et al., 2011), control policies and early warning of risks. These studies can also provide valuable information as to how effective management actions have been in mitigating effects of anthropogenic land use (Sankey et al., 2018). In short, the objective of this study is to demonstrate how the topographic conditions associated with a dune system located in the Buenos 
Aires Province determine the characteristics of the extension, permanence, and recurrence of floods in the region.

\section{Study area}

Southern South America, particularly the central-western region of Argentina, shows an extensive Quaternary aeolian cover (Zarate and Tripaldi, 2012; Contreras et al., 2018; Mehl et al., 2018), known as the Mar de Arena Pampeano (Pampean Sand Sea) (Iriondo, 1990; Tripaldi et al., 2018), where stabilized dune fields are common and potentially reflect drought variability in the Late Quaternary (Tripaldi and Forman, 2007). These dune systems comprise a large variety of dune morphologies and occur in a variety of environmental settings under different climatic conditions, from humid-subhumid to semiarid-arid (Tripaldi and Zarate, 2016). An important part of these dunes was locally reformed in the past 100 years, which apparently coincides with intensified agrarian use and drying in the late $19^{\text {th }}$ and early $20^{\text {th }}$ century (Tripaldi and Forman, 2007). The shallow lakes in the Pampean region record water run-off, as well as are affected by the wind action, whose predominant direction is from the north and have a wide range of intensities. These dynamics were associated with pronounced droughts followed by floods, likely because of a marked seasonality in the annual precipitation regime and a regionally unstable environment (Stutz et al., 2014; Mehl et al., 2018). The study area covers 21,040 $\mathrm{km}^{2}$ in the central-western region of Buenos Aires Province (Fig. 1), described by Dangavs (2005) as: "sandy Pampa, which lacks drainage, with abundant troughs in interdune depressions in an N-NE direction and relicts of old drainage ditches". The fact that the region is crossed by dunes, that hinder the runoff, is one of the factors that determine the development of surface drainage (Taboada et al., 2009). This region has smooth slopes (Quirós et al., 2002), is made up of a large plain with a smooth regional gradient from west to east, the average of slopes is $25 \mathrm{~cm}$ per km (Taboada et al., 2009). The regional hydrography is characterized by a diagonal system of stagnant waters with a remarkable alignment of its shallow lakes and waterlogged areas. This system contains shallow lakes as reservoirs associated with the longitudinal dunes, partly active due to current removals and, in part, strongly devastated in fixed or semifixed sandy areas, that may continue approximately along the $61^{\circ} 30^{\prime} \mathrm{W}$ meridian, following the sinuous course of old drainage lines. Throughout this region, numerous basins, mostly small, are often only flooded during prolonged rainy periods, arranged in wavy lines distributed like a string of beads (Frengüelli, 1956).

At the S and SW there is a parabolic dune field of approximately $20,200 \mathrm{~m}^{2}$ with a SW-NE orientation in which agricultural and livestock activities are developed. The width of the dunes ranges from 2 to $5 \mathrm{~km}$, whose heights range between 2 and $6 \mathrm{~m}$. Like the longitudinal dunes there are shallow lakes, with an average length of $200 \mathrm{~m}$ in normal periods, dry completely or occupy the entire interdune sector, reaching a maximum length of $6 \mathrm{~km}$ (Contreras et al., 2018). The water bodies in this region were characterized by Quirós and Drago (1999) as a shallow, whose depth average range between 0.7 and $7.3 \mathrm{~m}$. Consequently, these strong morphometric changes represent potential flood risks, considering that it is an area of great agricultural exploitation and that, in many cases, these buckets are over the boundaries of the peri-urban areas of the different localities of the region. Finally, this field dune field is divided into Eastern (wet) and Western (dry) sectors separated by the $650 \mathrm{~mm}$ isohyet.

The region is characterized by a temperate climate, with significant climate variability, where the occurrence of long periods of floods and droughts affect the availability of water resources. Most of the region receives a range of precipitation between 650 and 1,100 mm/year (Aliaga et al., 2017) and presents a NE-SW precipitation gradient (Tripaldi et al., 2018). This regime of precipitation can also amplify the role of vegetation as an active agent in the sandy landscape evolution (Durán et al., 2008). Regionalization of the Pampean climate in the Buenos Aires Province carried out by Aliaga et al. (2016), according to its rainfall regime and temperature distribution, indicates that the study area is located in the humid subregion. Within this subregion, annual precipitation is higher than $650 \mathrm{~mm}$, and moving water is often the dominant natural process shaping the land surface (Charlton, 2007; Liu and Coulthard, 
2015). The annual precipitation shows a marked seasonality of high rainfall during the autumn (MarchApril) and spring months (October-November), whereas winter is the dry season. This average difference is inherited from the inter-annual variability in rainfall across the region (Barrineau et al., 2019). This zone is affected by extreme precipitation and drought events with variable duration and intensity. In the last 50 years in Argentina, a succession of severe droughts and significant flood periods occurred, all of them affecting both the economic activities and the number of shallow lakes that characterized the area. These events included the plain areas, where the dynamics of water resources are directly related to the regularity, intensity, and frequency of rainfall. On the other hand, during dry events a decrease in the cultivated areas and an increase in aeolian erosion processes were observed (Aliaga et al., 2016).

The shallow lakes in this region are not located in an environmentally protected area, therefore its resources are anthropically exploited, although in many cases in low use. Furthermore, from the trophic standpoint, they were characterized as very variable, from eutrophic to hypertrophic and has been found high biomass of their biotic communities, with a variable abundance of piscivore, planktivore (with a predominance of Odontesthes bonariensis) and filtering fishes (Quirós et al., 2002). The fauna present in these shallow lakes is in turn affected by both the annual climatic seasons and drought and flood periods. In droughts have been documented generalized fish mortalities, while in periods with positive hydric regimes have been found algal blooms and high abundance of fish (Quirós et al., 2002).
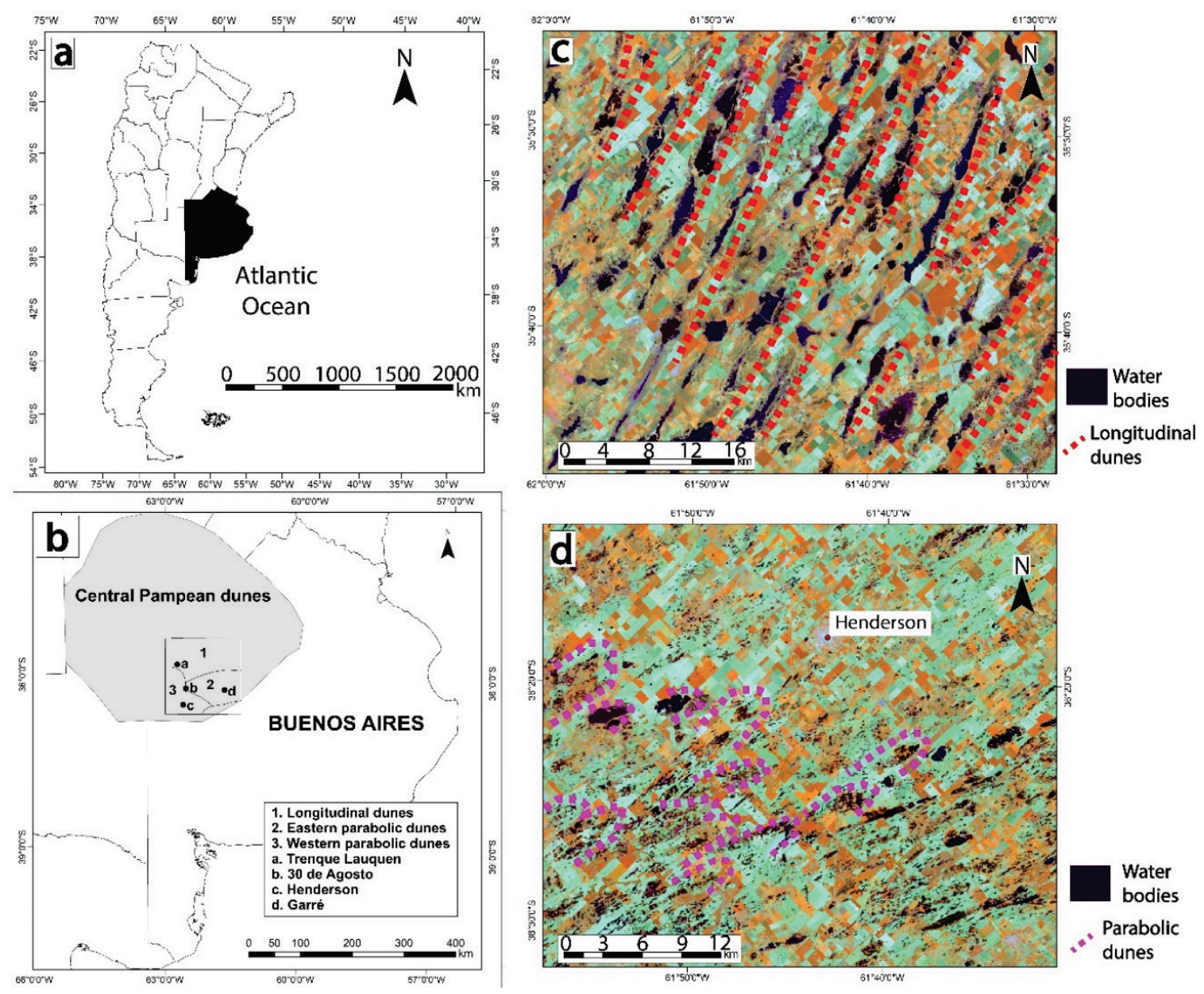

Figure 1. Study area and comparison between water bodies and dunes a) Argentina and Buenos Aires Province. b) Delimitation of dune fields. c) Longitudinal dunes. d) Parabolic dunes. Modified from LANDSAT 5 TM Path/Row 227/85 image (corresponding to 12/16/2008). 


\section{Materials and Methods}

To analyze wet and dry conditions, we used the Standardized Precipitation Evapotranspiration Index (SPEI), which takes into account both precipitation and potential evapotranspiration in its formulation to expresses the water supply-demand relationships in order to understand for climate change influences (Vicente-Serrano et al., 2012).

The SPEI is a drought index that incorporates the effect of evapotranspiration on drought analysis to identify changes in water demand. The SPEI was computed at 1 (month) and 12 (annual) timescales using a 34 years-long monthly. The monthly values (SPEI-1) allow knowing the distribution and the percentage of occurrence of extreme events during the year, while the annual values (SPEI-12) allow intra-annual comparisons during the study period. The datasets have a spatial resolution of $0.5^{\circ}$ by $0.5^{\circ}$ and were extracted for grid point in Lat. -35.75 and Long: -62.25 . For drought analysis, the grading is similar to the SPI with drought categories as: extreme (SPEI $>-2.0)$, severe $(-1.5<$ SPEI $<$ - 1.99), moderate $(-1.0<$ SPEI $<-1.49)$ and near normal $(1.0<$ SPEI $<-1.0)$.

The spatial analysis of 31 satellite images over the period (1986-2017) and its relationship with the SPEI 12-month made it possible to make a comparison of the study area during extreme events of flood and drought. To determine the role that dunes play in the distribution and morphometric characteristics of the shallow lakes that characterize the area during extreme events, two historical cases of flood and drought were selected. The LANDSAT 5 TM Path/Row 227/85 image (corresponding to 12/16/2008) was used for the extreme drought event, while the image LANDSAT 8 OLI Path/Row 227/85 was employed for the extreme flooding event corresponding to 13/03/2017.

The distribution and number of shallow lakes in both years were determined by a combination of bands 4-5-3 for the LANDSAT 5 TM image, while 5-6-4 for the LANDSAT 8 OLI image, both generated in ArcGIS 10.1 (Odriozola and Contreras, 2016). The use of this methodology was chosen based on the least amount of errors that are generated in the unsupervised classification using the IsoClusters tool of ArcGIS 10.1. The results were represented cartographically.

Morphometric variables of the shallow lakes were estimated through the comparison of both years. The studied variables were surface area and lake density. The lake density is defined as the area occupied by lakes in a region, referred to as the total area and expressed as a percentage. The SPEI-12 was used to determine their relationship to lake density.

The topographic description was made based on the 90m SRTM image corresponding to the study area. Once the digital elevation model was generated, topographic profiles were generated using Path Profile spatial analysis tool of the Global Mapper 19.1 software. Flooding and flood models were generated using the Water level tool of the Global Mapper 19.1. The determination of the topographic characteristics corresponding to the dune area and its possible responses during extreme flood and drought events was carried out using $1 \mathrm{~m}$ of water level increase with the water level increase tool.

\section{Results and Discussion}

The intra-annual analysis of SPEI 1 has shown that in the study area there is a predominance of extreme floods over extreme droughts. On the other hand, the highest humidity values are distributed from spring to autumn, but mainly between late summer and early autumn (Fig. 2). This situation is due to the predominance of winds from the $\mathrm{N}$ and $\mathrm{NE}$ coming from the South Atlantic anticyclone, which contributes humidity to the region. On the other hand, extreme drought events are found in the winter, at which time the SW winds from the South Pacific Ocean predominate, characterized by being cold and dry. 


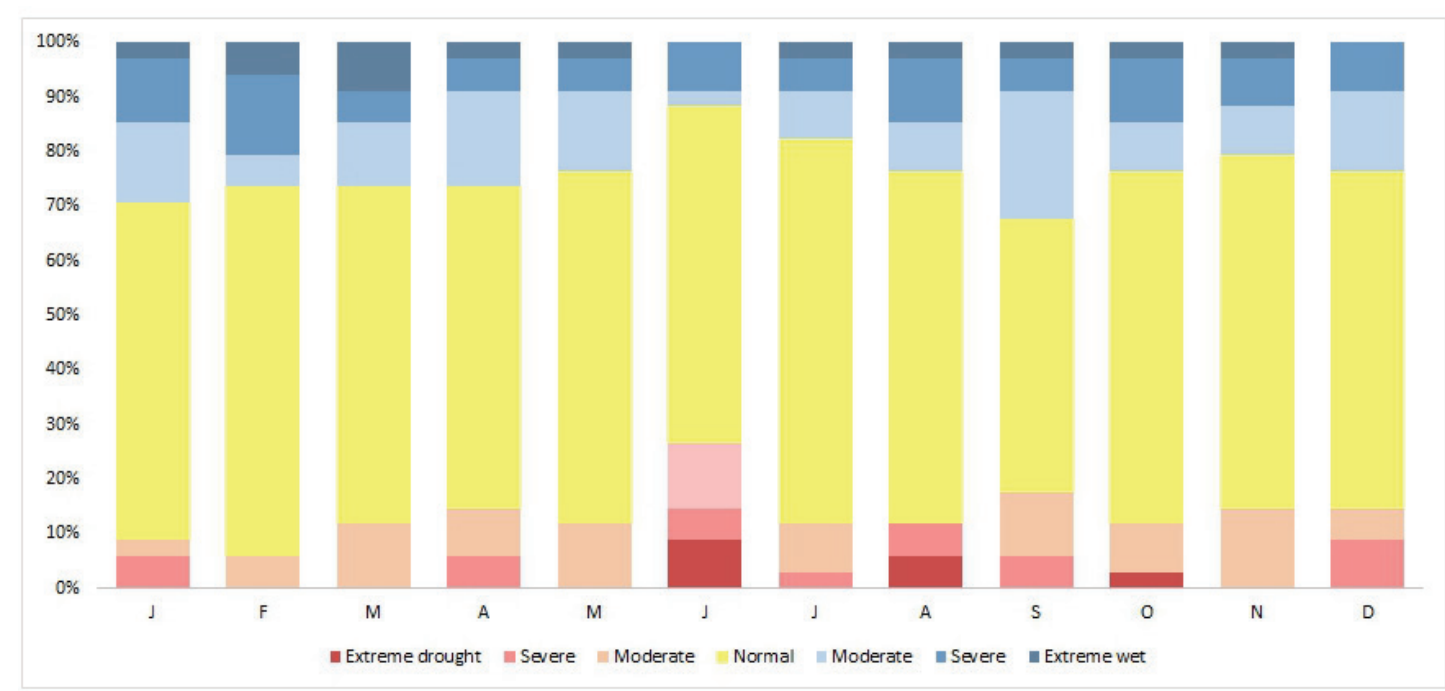

Figure 2. Annual distribution and percentage of occurrence of extreme flood and drought events. Period 1984-2017.

The comparison of SPEI 1 between 2008 and 2017 shows significant differences in both extreme events (Fig. 3). Although the year 2017 was characterized by extreme floods, this event was fueled by the manifestation of the El Niño phenomenon during 2015 and 2016, according to information from the National Oceanic and Atmospheric Administration (NOAA, 2020). In this sense, the water-saturated soils, added to the abundant rainfall during 2017, generated the overflow of the shallow lakes, which have a limited capacity for water retention, mainly those located to the S and SW of the study area.

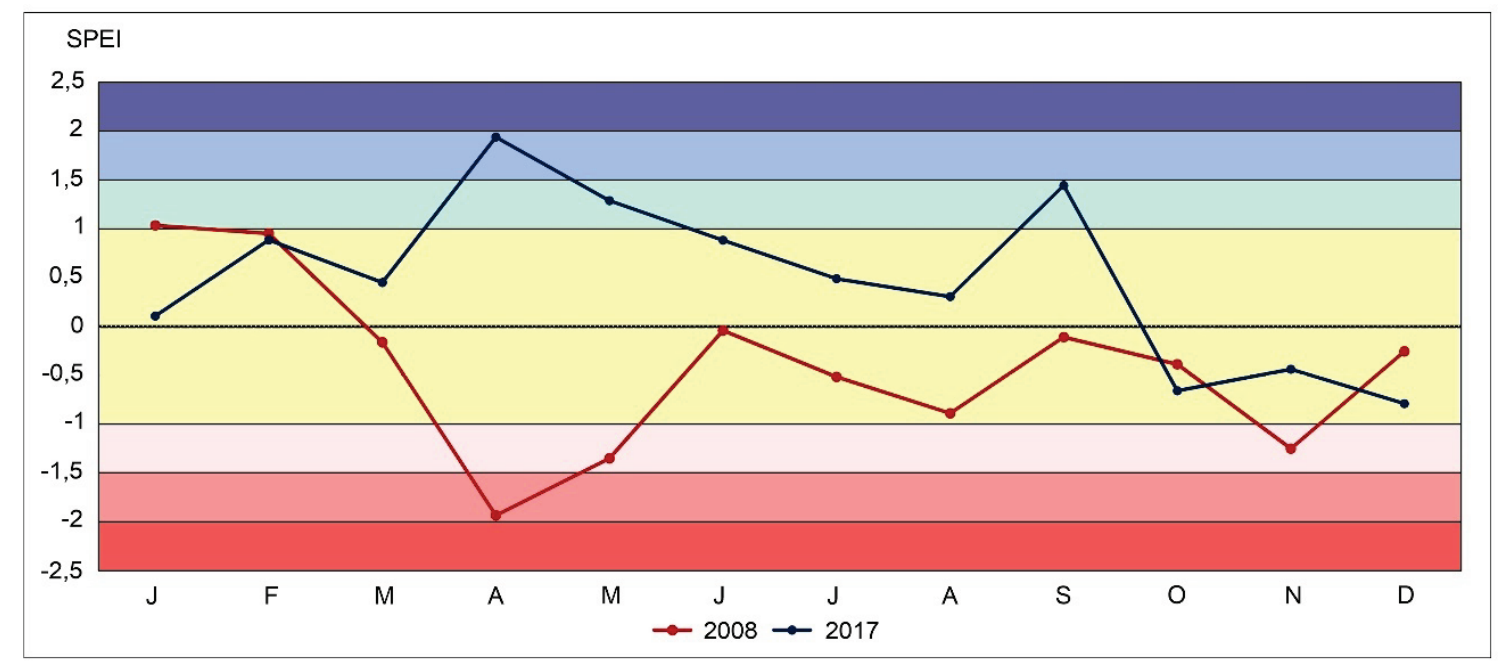

Figure 3. Comparison between SPEI 1 values for the years 2008 and 2017

On the other hand, in the first half of 2008, mainly during April, the values of SPEI 1 were inverse to those of 2017. This is not a minor fact since an extreme drought event was manifested at the same time than an increased annual rainfall and during the month with the greatest recurrence of the expected occurrence of extreme flood events. Subsequently, during June, in both years there was a slight trend towards extreme drought events; however, they remain within normal values until September, when a rebound was observed. In this case, in 2017 reaches severe flooding events again, allowing water to enter in the region. 
In summary, these results evidence that, in the study area, the precipitations registered during the first quarter of the year, determine the hydrological levels of the water bodies, being significant the influence of the winds from the NE to the continental interior, mainly for the western portion of the study area.

In the region of parabolic dunes (Fig. 4), the magnitude of the floods did not change in relation to the low percentage of lake density in extreme flood events. However, the response of the lake density between the longitudinal dunes and the eastern parabolic dunes, except for the difference in values, was similar because both dune systems are in a more humid sector of the study area.

The western parabolic dunes, being in a more arid sector, only exceeded $10 \%$ in lake density in the most extreme years of flood events with a difference of 30 years. The limited recurrence of extreme flood events could explain the lack of investments in storm drainage works in the region, which is why, in the floods of 2017, the channeling was done privately and without impact studies, which generated numerous legal conflicts, as will be explained later.

Comparing the distribution of floods to the north of the study area between 2008 (driest year of the period) and 2017 (last year of extreme flooding), the shallow lakes were aligned following the orientation of the longitudinal dunes in both meteorological conditions of flood and drought. Towards the south, in the period of drought, surface water was basically absent in the area (Fig. 4). In the wet period (2017), large flooded areas were observed (Fig. 5), which allowed the establishment of a boundary between the elongated shallow lakes within the longitudinal dunes to the north and significant extensions of small shallow lakes interdunes to the south (Fig. 5).

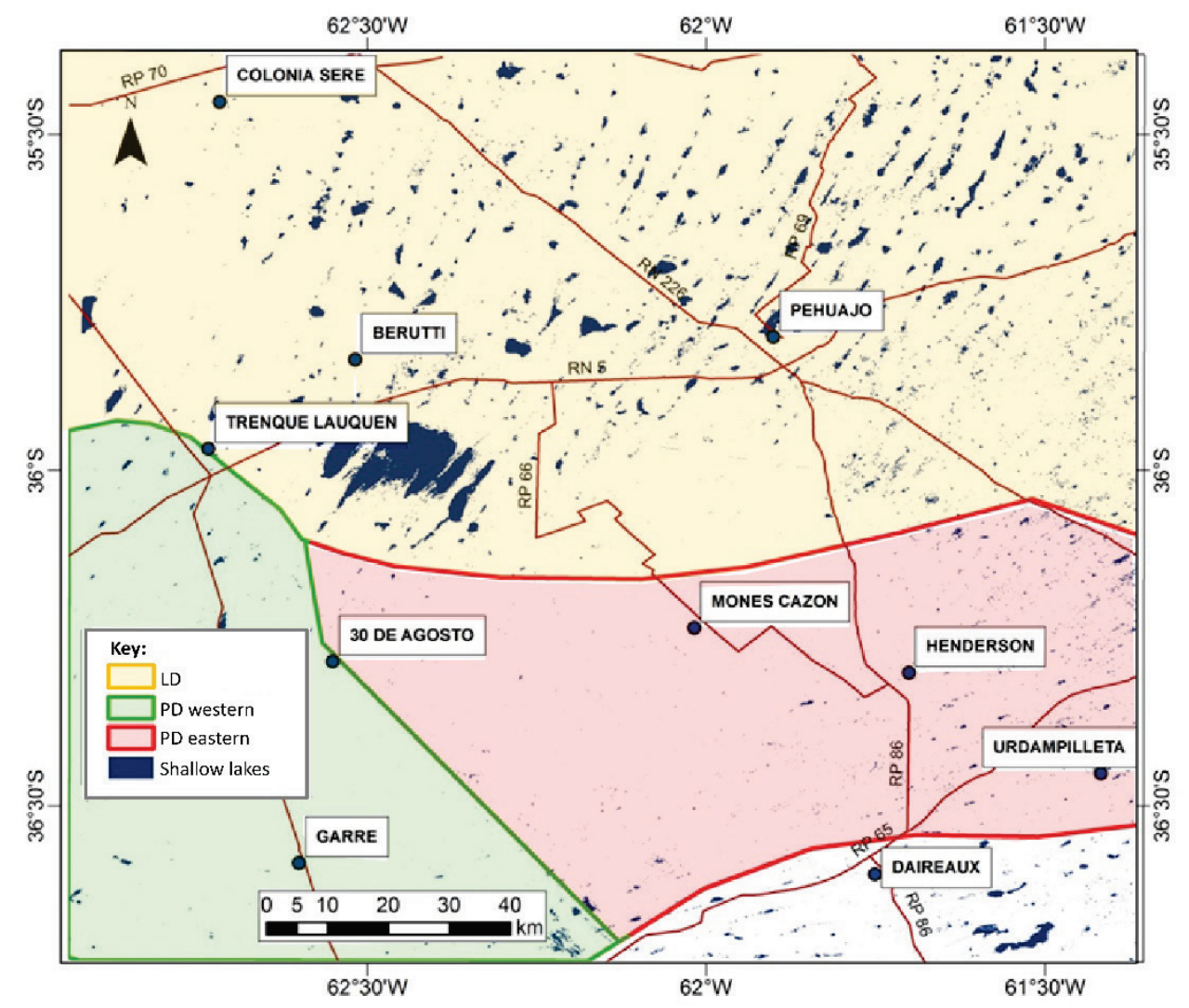

Figure 4. Distribution of shallow lakes and ponds in the central west of Buenos Aires Province during an extreme drought event, December 2008. Delimitation of the area of longitudinal (LD) and parabolic (PD) dunes in the study area. 


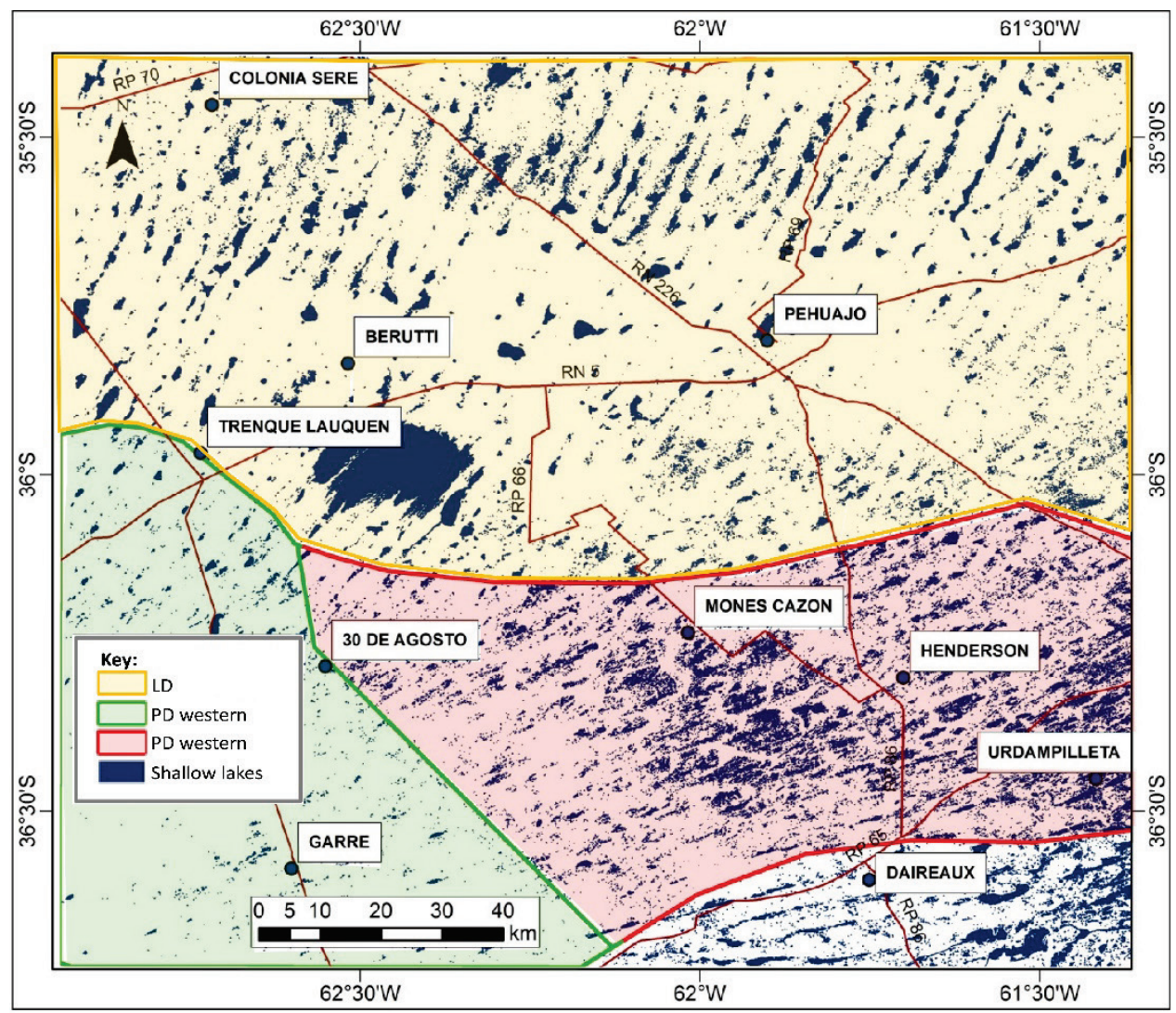

Figure 5. Distribution of shallow lakes and ponds in the central west of Buenos Aires during an extreme flood event, March 2017. Delimitation of the area of longitudinal (LD) and parabolic (PD) dunes in the study area.

Lake density (Table 1) was employed to compare the total study area into sub-regions (Fig. 4): the sector of longitudinal dunes and the sector of parabolic dunes, which in turn is subdivided into eastern areas (more significant presence of shallow lakes) and western areas (drier). Therefore, the water fluctuation of the landscape could be estimated from the values of lacustrine density in both events and, on this basis, to establish temporal and spatial comparisons.

Table 1. Comparison between the occurrence of shallow lakes and ponds during extreme events of drought and flood in the center-west of Buenos Aires (years 2008 and 2017, respectively)

\begin{tabular}{|c|r|r|r|r|r|}
\cline { 2 - 6 } \multicolumn{1}{c|}{} & Area & \multicolumn{2}{c|}{2008} & \multicolumn{2}{c|}{2017} \\
\cline { 2 - 6 } \multicolumn{1}{c|}{} & $\mathrm{km}^{2}$ & $\mathrm{~km}^{2}$ & \multicolumn{1}{c|}{$\mathrm{km}^{2}$} & $\%$ \\
\hline Study area & 21,040 & 6,928 & 33 & 14,389 & 68 \\
PD Total & 9,017 & 732 & 8 & 4,592 & 51 \\
PD Eastern & 5,358 & 584 & 11 & 4,106 & 77 \\
PD Western & 3,659 & 147 & 4 & 486 & 13 \\
LD & 12,023 & 6,196 & 52 & 9,797 & 81 \\
\hline
\end{tabular}

The longitudinal dunes sector has more stable conditions regarding the temporality and extension of its lakes. In contrast, the shallow lakes associated with parabolic dunes, which are particularly sensitive to changes in environmental controls (e.g., temperature, precipitation, and wind regime) and human disturbances (Yan and Baas, 2017), present a rapid response and, therefore, would act as sentinels in scenarios of change, both current and future. 
The longitudinal dunes allow channeling and temporary connections between the depresions seen in the landscape with the reappearance of ponds in extreme flood events, which accommodate excess water and can achieve considerable size (Stanistreet and Stollhofen, 2002). There are no overflow processes, or they are reduced and, therefore, the flooded or waterlogged surfaces are smaller (Fig. 5). On the contrary, the interdune area of the parabolic dunes is extensive (reaching values of up to $6 \mathrm{~km}^{2}$ ) and flat, which enhances the processes of overflow and waterlogging of the shallow lakes, and consequently, large areas of flooded ground are generated during heavy precipitations.

Aeolian dune-field patterns reflect the complex external environment within which the pattern evolves (Ewing and Kocurek, 2010; Yan and Baas, 2017) and are sensitive to climate change (Xu et al, 2015) over a wide range scales (Ewing et al., 2015). In this case, regions with different type of dunes (parabolic and longitudinal) show essential differences in terms of the number of lakes or the area covered by water or floods in the interdune areas. These lake fluctuations can be associated with subdecadal variability (Forman and Pierson, 2003). The differences found are related to the levels of moisture availability (Bullard and Livingstone, 2002) and the amount of rainfall in the wet period. The study area is located in the transition zone between dry and humid climates of the Pampean region (Aliaga et al., 2016), separated by the $650 \mathrm{~mm}$ isohyet. During extreme flood events, this limit shifts to the SW, incorporating the western parabolic dune sector into the wet region. On the contrary, in extreme drought events, the limit displaces towards the NE, which results in the shallow lakes of the eastern parabolic dunes sector drying out completely; during such periods the longitudinal dunes maintain a higher number of permanent shallow lakes, being within the humid region.

The highest percentage of lake density occurred in the longitudinal dunes, coinciding with a very strong flood event in 1987 (Fig. 6). Subsequently, the flood peaks reached $20 \%$, a number that reversed in 2004, with heavy investments in projects of storm drainage engineering towards the Salado River basin, in direction to the NE. According to the Ministry of Economy of the Argentine Republic, more than 300 US million dollars were invested in rural areas to prevent future floods (UCOFIN, 2012). After that date, a decade associated with aridity began, only increasing the values of lake density to 15 $\%$ during the first months of 2017 , where abundant rainfall occurred.

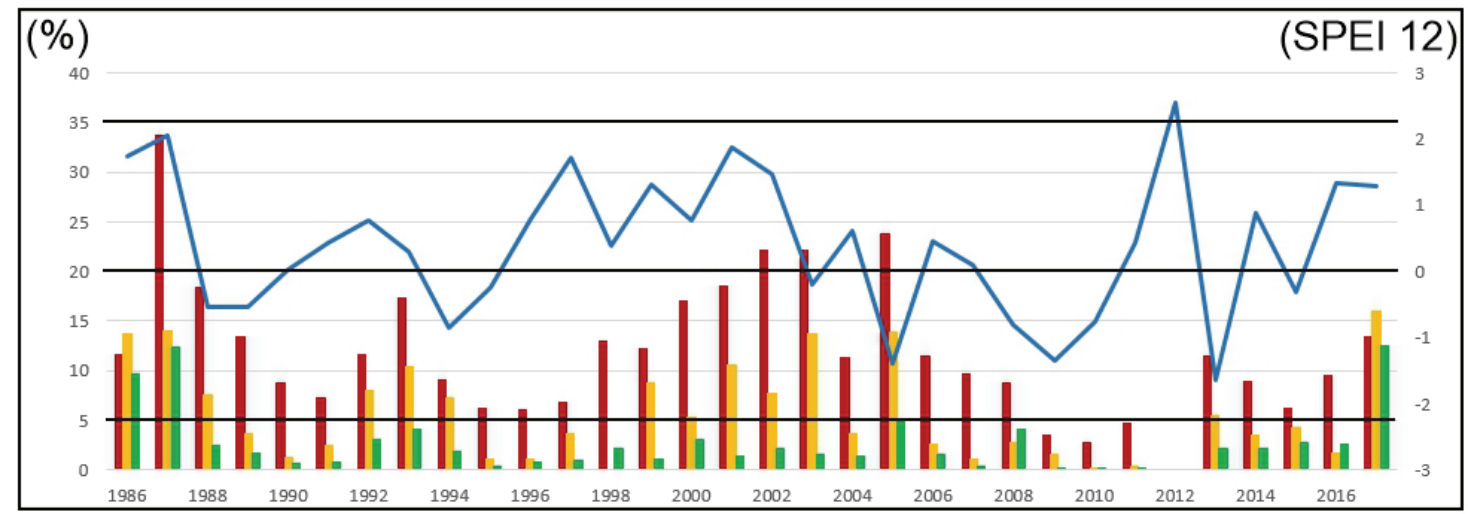

Figure 6. Comparison of lake density between the three regions and the SPEI 12. In brown, the longitudinal dunes field, in yellow, the field of eastern parabolic dunes, and in green, western parabolic dunes field.

In 2014, Argentina returned to a wet period with abundant rainfall during 2015 and 2016 associated with "El Niño" phenomenon that lasted until mid-2017 when droughts returned (Figure SPEI 12). During the wet period in the study area, we observed significant differences in the landscape, mainly in the density and area of the shallow lakes. In such a small area, we distinguished how the rainfall and the landforms (the dunes type) condition the distribution, density, and expansion of the water bodies. 
The quantitative analysis of both satellite images in the wet period allowed us to calculate the total area corresponding to lakes and ponds as well as the flooded areas (Fig. 7). On 15/01/2014, there were $8,626.92 \mathrm{~km}^{2}$ of water in the region, where $60 \%$ corresponded to shallow lakes and ponds and the remaining $40 \%$, to flooded areas. On 10/30/2014, the water inundated region covered $21,573.89 \mathrm{~km}^{2}$, where $59 \%$ belonged to shallow lakes and ponds, and the rest to flooded areas.

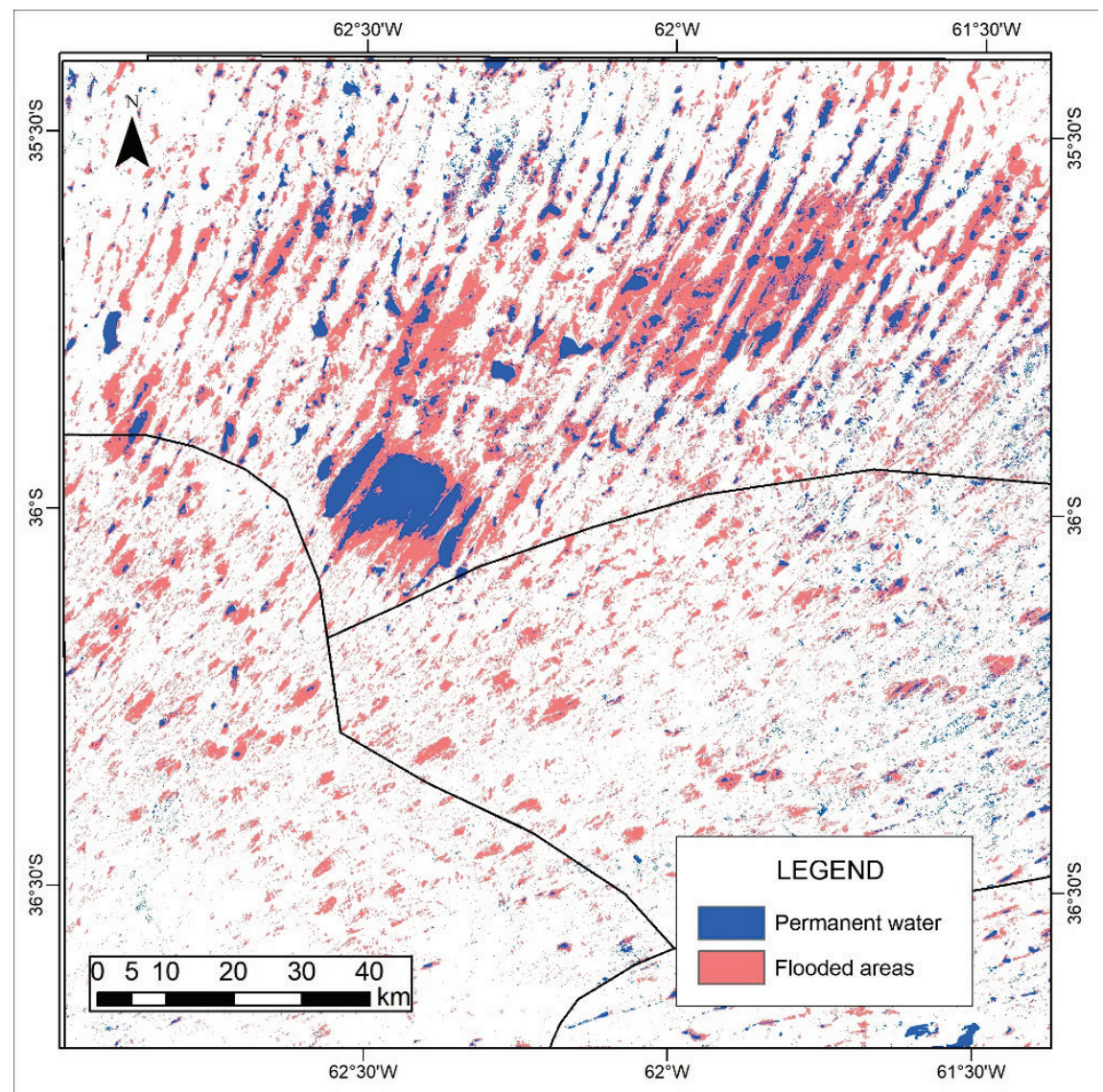

Figure 7. Comparison between water bodies and flooded areas in the study area between 2008-2017.

The results of the comparisons between the two dates and between the geomorphological regions reveal even more significant differences. On $01 / 15 / 2014$, of the $8,626.92 \mathrm{~km}^{2}$ with shallow lakes and flooded areas, only $303.45 \mathrm{~km}^{2}$ belonged to the parabolic dunes' region, and of that surface, $72 \%$ corresponded to flooded environments. The remaining $28 \%$ were water bodies, i.e., before the wet period started, $91 \%$ of the water in the study area was in the humid wetland region. Ten months later, the area with shallow lakes and flood increased to $23,506.65 \mathrm{~km}^{2}$, where $92 \%$ corresponded to the sector of the longitudinal dunes and the remaining $8 \%$ to the parabolic dunes. Although the proportions between the areas of shallow lakes and the waterlogged sectors are maintained for longitudinal dunes (60\% shallow lakes and $40 \%$ waterlogged sectors), the most significant differences are those of the parabolic dunes, where the area goes from $28 \%$ in January to $49 \%$ of water bodies in October and the remaining $51 \%$ to flooding areas. In summary, whereas in the humid, aligned dunes region, the landscape responded to flood events with an increased water-covered ground, the patterns that dominate the landscape remained the same. In the region of parabolic dunes with a drier climate, the changes are more significant, generating substantial landscape changes associated with the water-covered ground. Undoubtedly, it is a complex situation, since environments that vary so much in short periods expose the population to issues most associated with the risk of flooding (Contreras and Paira, 2016).

In the longitudinal dunes, the greater availability of water, in addition to the channeling of the interdune areas, allows the development of agricultural activities in the higher interfluvial areas (Fig. 
1c), leaving the waterlogged areas for livestock exploitation. On the other hand, parabolic dunes have important implications for land use as vegetated dune fields often carry significant socio-economic activity (Yan and Baas, 2017). Therefore, the landscape with parabolic dunes and a drier climate allows for agricultural activities to be carried out on both the dunes and the interdune areas. The use of these sectors with higher risk is not only linked to larger farms, but it is also due to the presence of fine sedimentary material in the soil composition that provides more nutrients than the poor soils on sandy dunes.

Changes in these types of systems have many local environmental and economic impacts (Xu et al., 2015). In this region, as a result of these socio-environmental interactions, the most significant flood damages in agriculture will be found in the parabolic dunes region. Although the levels of the overflow of the shallow lakes or the increase in the water level are inferior to that of the longitudinal dunes, the floods are sufficiently significant to harm an annual harvest (Fig. 1d).

Postdepositional modification of dune morphology is primarily a result of erosion by rain and wind, bioturbation and human disturbance (Ivester and Leigh, 2003). Under certain conditions, parabolic dunes may be transformed into other dune morphologies (Yan and Baas, 2017), including longitudinal dunes (Meurisse et al., 2005). In this study area, abundant and frequent precipitations erode the crest of the parabolic dunes, leaving the disposition of their arms in the landscape and generating the longitudinal dunes characteristic of the region (Contreras et al., 2018). In the parabolic dunes sector, extreme drought events are more frequent and, therefore, the water bodies dry up completely. On the surface of the dry interdune areas, a large quantity of loose fine sediments rebuilds the parabolic dunes when transported by the wind (Contreras et al., 2018). The parabolic dunes remain active due to either anthropogenic pressure or prolonged drought (Yizhaq et al., 2007).

Sand dunes can deflect and confine flows, dam and divert water courses, and thus, determine the position of many contemporary depressions and channels (Maroulis et al., 2007; Liu and Coulthard, 2015). In accordance to these effects, the DEM and topographic profiles of both types of dunes (Figs. 8 and 9) showed that the lakes in the longitudinal dune area (Fig. 8) have channel-like shapes and, in general, the interdune area are permanently inundated. In contrast, in the parabolic dunes area, the lakes are only filled during floods (Fig. 9).

The sedimentary records in dune systems and their related geomorphic forms respond to climatic and environmental changes (McLaren et al., 2009; Thomas and Bailey, 2019). Dangavs (2005) correlated the degree of eutrophication of shallow lakes in relation to age. Shallow lakes occupying older (Pleistocene) depressions are deeper; therefore, they tend to have higher water transparency and presence of macrophytes. On the other hand, in depressions formed during the Holocene, lakes are shallower and either turbid or directly dry during drought periods.

During events of extreme drought in the region, there are significant socioeconomic consequences, such as the reduction in the area of crops and pastures as the area occupied by bare ground increases and so does evaporation (Ferrelli, 2012). In addition, the effects of this phenomenon are observed in a reduction of the depth of the shallow lakes (Quirós et al., 2002). In contrast, an increase in rainfall generates an extension of the cultivated area, an increase in drinking water for the inhabitants and an increase in lake surface area (Sosnovsky and Quirós, 2006; Ferrelli, 2012) as well. If this increase exceeds the load capacity of these shallow lakes, flooding and waterlogging processes begin.

In summary, the topographic profiles help to explain why the two dune landscapes do not originate the same responses during the same extreme event, despite being very close to each other. The region of parabolic dunes is in a latent state of vulnerability to the occurrence of floods. The topographic differences are observed in both the windward and the leeward sides of the dunes, where we perceived that the water level on one side was two or three meters higher than the other (Fig. 9b). The crest of the dune would act as a barrier or natural dam, preventing the passage of water to the next interdune area, considering that there is a general slope with direction W-E. 


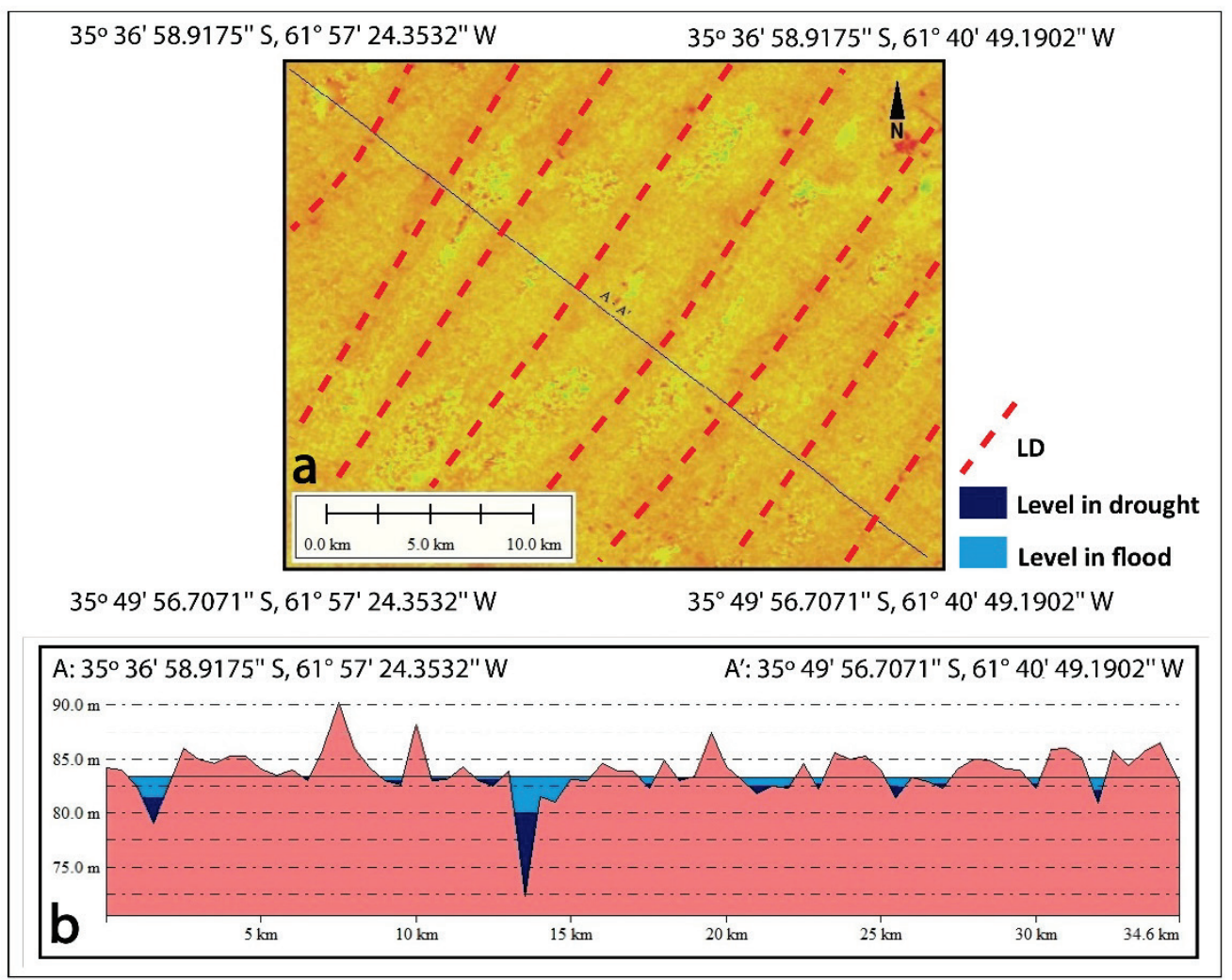

Figure 8. a) Location of cross section $A-A^{\prime}$ in the DEM. b) Topographical profile of the area of longitudinal dunes and distribution of shallow lakes with their respective water levels during extreme events of drought and flood.

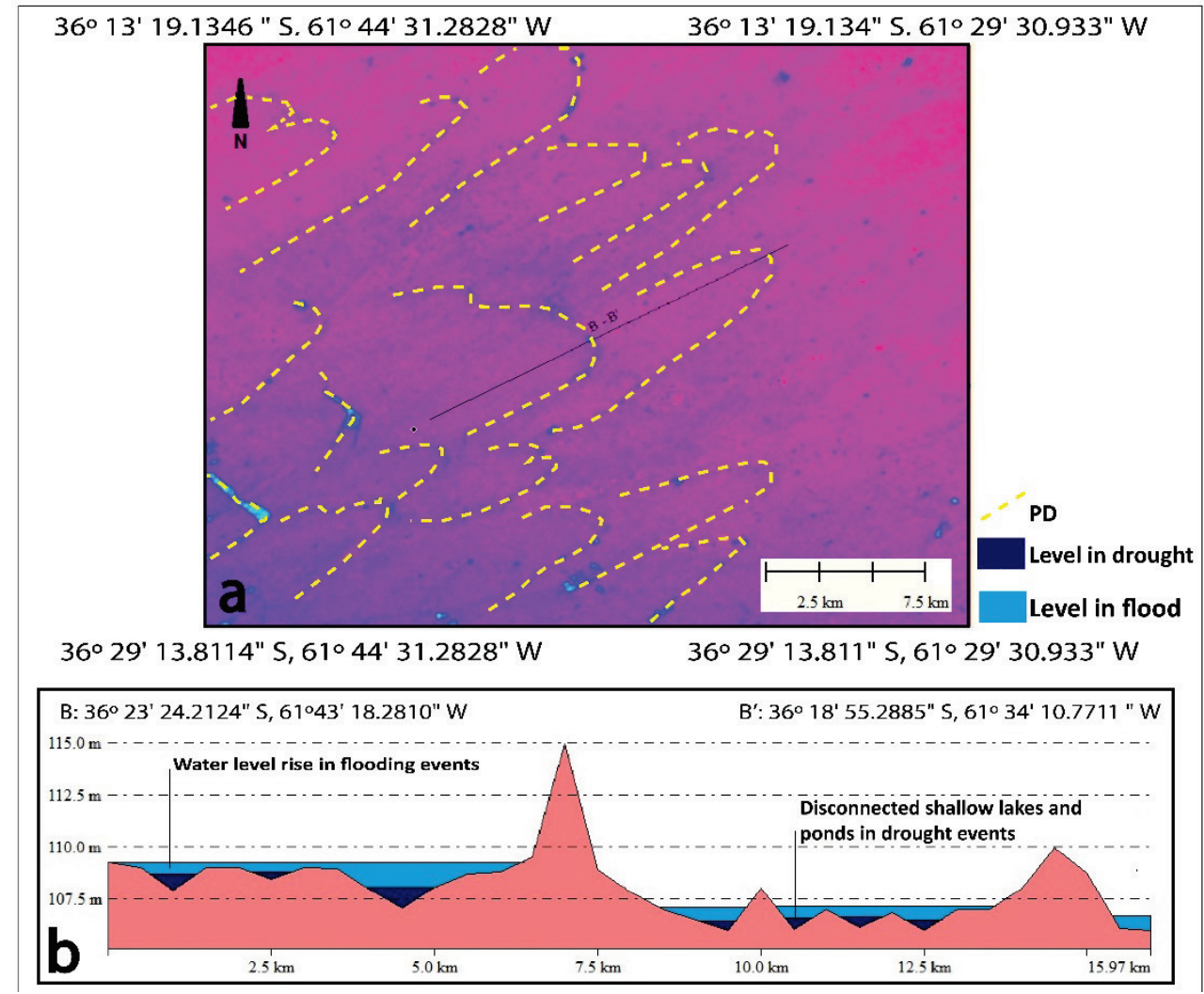

Figure 9. a) Location of the cross-section $B-B^{\prime}$ in the digital elevation model. b) Topographical profile of the parabolic dunes and distribution of shallow lakes with their respective water levels during extreme drought and flood events. 
In this framework, in mid-2017, different localities were affected by flooding, in both urban and rural areas. Stakeholders proceeded to reduce the inundated zones by clandestine ditches and channels (InfoCielo, September 20,2017). Thus, they opened up a way through the dunes, in the same way as in other areas worldwide -especially in those that have been fixed due to agricultural activities and recent engineering projects (Zeng et al., 2018). This allowed the circulation of water from one interdune area to another, generating an extraordinary increase in the water levels registered, even surpassing historical values.

It is not the first time that districts in the region have come into conflict because of floods, and in this occasion, the municipality of Trenque Lauquen filed a criminal complaint against the municipality of Daireaux (Fig. 1) and, at the same time, made a formal complaint about clandestine channels to the Water Authority of Buenos Aires Province. In the meantime, the municipality of Trenque Lauquen stopped the drainage by closing the passage of water (InfoCielo, September 20, 2017). These social conflicts caused by emergency actions carried out without contemplating any possible environmental impacts are persistent in locations at risk and could even affect those communities who were not under any risk.

The severity and complexity of the water crisis are, for Somlyody and Varis (2006), due to sectoral response management and responses to crises and problems without a predictive attitude and systematic approach, among other things. The flood events that occurred in the west of Buenos Aires Province during 2017 was a clear example of a lack of territorial planning and management that included the geographical variables, both human and natural. The management of the early warning occurrence of, for example, floods should not be focused strictly on climatic variables because, as it has been shown, differences in the topographic conditions of a place can result in reducing or enhancing the risk.

\section{Conclusions}

Buenos Aires Province has witnessed extreme flooding and drought events through historical times; however, in recent years, due to climate variability, the events characterized by heavy rainfall are increasingly recurrent. In this study, we show how topography increases the risk of flooding, shortage of drinking water, stakeholder conflict, etc. The same precipitation event does not affect limiting areas in the same way, due to the presence of geomorphological differences.

The development of aligned longitudinal dunes allows the channeling of the shallow lakes overflow in flood events while contributing to the water permanence during droughts. However, the parabolic dunes respond inversely, in extreme drought events the interdune areas are arid, whereas in flood events the overflows of the shallow lakes occupy large areas of the landscape that contains them. Furthermore, these dunes constitute a natural barrier to the general slope W-E that, when crossed by engineering works (in many cases clandestine), flood events take on historical dimensions.

Using the map with the distribution and variability of precipitations in the Pampean region and the distribution of dunes as a reference, it was possible to verify that both, the longitudinal and the eastern parabolic dunes are within the humid region, whereas the western parabolic dunes are in the dry one. The $650 \mathrm{~mm}$ isohyet displacements determine the presence of shallow water bodies, such as semipermanent puddles.

Predictions about flooding or drought risk are crucial for the management of a region affected by climate variability and with certain topographic features. The need for territorial management that provides adequate guidelines on how to mitigate natural disasters are needed. A systematic view of flood vulnerability is the key to minimizing the adverse effects these events bring with them.

This paper determines how three aspects linked to flood risk converge in a relatively small area but present significant differences: 1.- Climatic characteristics: longitudinal dunes in the NE have larger and recurring precipitations, and their water elasticity varied considerably between the years of extreme 
moisture and drought in comparison with the SW area, which is more arid and where flood events occurred after 30 years; 2.- Types and distribution of geoforms: aligned dunes generate more channeled floods, simulating river runoff, while parabolic dunes create large flood areas similar to shallow lakes or ponds; and 3.- Anthropic intervention: strong investments against the reduction of flooded areas in the aligned dunes has reduced more than half the lake density during extreme flood events. In contrast, the reduced or lack of works in the region of parabolic dunes led not only to floods similar to those that occurred 30 years ago, but in turn led to illegal engineering works, further aggravating the situation generated by the natural disaster.

\section{Acknowledgements}

This work was carried out with the aid of a grant from the Inter-American Institute for Global Change Research (IAI) CRN3038 which is supported by the US National Science Foundation (Grant GEO-1128040). This paper is partially financed by the projects 19Q002 of the SGCyT - UNNE, PICT2018-00636-DT and the Universidad Nacional del Sur.

\section{References}

Aliaga, V.S., Ferrelli, F., Alberdi Algañaraz, E.D., Piccolo, M.C., 2016. Distribución y variabilidad de la precipitación en la región Pampeana, Argentina. Cuadernos de Investigación Geográfica 42(1), 261-280. http://doi.org/10.18172/cig.2867

Aliaga, V., Ferrelli, F., Piccolo, M.C., 2017. Regionalization of climate over the Argentine Pampas. International Journal of Climatology 37(1), 1237-1247. http://dx.doi.org/10.1002/joc.5079

Al-Masrahy, M.A., Mountney, N.P., 2013. Remote sensing of spatial variability in aeolian dune and interdune morphology in the Rub' Al-Khali, Saudi Arabia. Aeolian Research 11, 155-170. https://doi.org/10.1016/j.aeolia.2013.06.004

Barrineau, P., Dobreva, I., Bishop, M.P., Houser, C., Forman, S., 2019. Deconstructing aeolian landscapes. Catena 174, 452-468. https://doi.org/10.1016/j.catena. 2018.11.038

Blumberg, D.G. 2006. Analysis of large aeolian (wind-blown) bedforms using the Shuttle Radar Topography Mission (SRTM) digital elevation data. Remote sensing of environment 100(2), 179-189. https://doi.org/10.1016/j.rse.2005.10.011

Bubenzer, O., Bolten, A., 2008. The use of new elevation data (SRTM/ASTER) for the detection and morphometric quantification of Pleistocene megadunes (draa) in the eastern Sahara and the southern Namib. Geomorphology 102(2), 221-231. https://doi.org/10.1016/j.geomorph.2008.05.003

Bullard, J.E., Livingstone, I. 2002. Interactions between aeolian and fluvial systems in dryland environments. Area 34(1), 8-16. https://doi.org/10.1111/1475-4762.00052

Carrivick, J.L., Rushmer, E.L., 2006. Understanding high-magnitude outburst floods. Geology Today 22(2), 6065. https://doi.org/10.1111/j.1365-2451.2006.00554.x

Charlton, R., 2007. Fundamentals of fluvial geomorphology. Routledge. London-New York, pp. 1-224.

Contreras, F.I., Mavo Manstretta, G.M., Perillo, G., Piccolo, M.C., 2018. Caracterización de médanos parabólicos de la región pampeana oriental, centro oeste de la provincia de Buenos Aires (Argentina). Latin American Journal of Sedimentology and Basin Analysis 25(1), 1-15.

Contreras, F.I., Paira, A.R., 2016. Aplicación del "índice de cambio" a las variaciones morfométricas de las lagunas de lomadas arenosas. El caso de Bella Vista (Corrientes, Argentina). Revista de Geografía 21, 31-38.

Courrech du Pont, S. 2015. Dune morphodynamics. Comptes Rendus Physique 16, 118- 138. https://doi.org/10.1016/j.crhy.2015.02.002

Dangavs, N. 2005. Ambientes acuáticos de la provincia de Buenos Aires. Actas del XVI Congreso Geológico Argentino. Geología y Recursos Minerales de la provincia de Buenos Aires, 2019-2035. 
Durán, O., Silva, M.V.N., Bezerra, L.J.C., Herrmann, H.J., Maia, L.P., 2008. Measurements and numerical simulations of the degree of activity and vegetation cover on parabolic dunes in north-eastern Brazil. Geomorphology 102(3-4), 460-471. https://doi.org/10.1016/j.geomorph.2008.05.011

Ewing, R.C., Kocurek, G., 2010. Aeolian dune-field pattern boundary conditions. Geomorphology 114(3), 175187. https://doi.org/10.1016/j.geomorph.2009.06.015

Ewing, R.C., McDonald, G.D., Hayes, A.G., 2015. Multi-spatial analysis of aeolian dune-field patterns. Geomorphology 240, 44-53. https://doi.org/10.1016/j.geomorph. 2014.11.023

Ferrelli, F., 2012. La sequía 2008-2009 en el sudoeste de la provincia de Buenos Aires (Argentina). Ecosistemas, $21,235-238$.

Ferrelli, F., Aliaga, V.S., 2016. Variabilidad de las precipitaciones y sus efectos sobre la respuesta espaciotemporal de cuerpos de agua en la Región Pampeana, Argentina. Huellas 20, 239-246.

Forman, S.L., Pierson, J., 2003. Formation of linear and parabolic dunes on the eastern Snake River Plain, Idaho in the nineteenth century. Geomorphology 56(1-2), 189-200. https://doi.org/10.1016/S0169$555 X(03) 00078-3$

Forte Lay, J., Scarpati O., Capriolo A., 2008. Precipitation variability and soil water content in Pampean Flatlands (Argentina). Geofisica Internacional 47(4), 341-354.

Frengüelli, J., 1956. Rasgos generales de la hidrografía de la provincia de Buenos Aires. Ministerio de Obras Públicas de la provincia de Buenos Aires. 17 p.

Frot, E., Wesemael, B. 2009. Predicting runoff from semi-arid hillslopes as source areas for water harvesting in the Sierra de Gador, southeast Spain. Catena 79, 83-92. https://doi.org/10.1016/j.catena.2009.06.004

Ho, L.T.K., Umitsu M., Yamaguchi Y., 2010. Flood hazard mapping by satellite images and SRTM DEM in the Vugia-Thu Bon alluvial plain, Central Vietnam. International Archives of the Photogrammetry, Remote Sensing and Spatial Information Science, Volume XXXVIII, Part 8, Kyoto, Japan.

Infocielo, 2017. Municipios en guerra por el agua: canales clandestinos y denuncias penales por inundaciones. Infocielo. http://www.infocielo.com/nota/83930/

Iriondo, M.H., 1990. The map of the South American Plains. Its Present State. Quaternary of South America and Antarctic Peninsula 6, 297-306.

Ivester, A.H., Leigh, D.S., 2003. Riverine dunes on the coastal plain of Georgia, USA. Geomorphology 51(4), 289-311. https://doi.org/10.1016/S0169-555X(02)00240-4

Kasprak, A., Bransky, N.D., Sankey, J.B., Caster, J., Sankey, T.T., 2019. The effects of topographic surveying technique and data resolution on the detection and interpretation of geomorphic change. Geomorphology 333, 1-15. https://doi.org/10.1016/j.geomorph.2019.02.020.

Kwak, Y., Kondoh, A., 2008. A study on the extraction of multi-factor influencing floods from RS image and GIS data; a case study in Nackdong basin, S. Korea. The International Archives of the Photogrammetry, Remote Sensing and Spatial Information Sciences 37 (Part B8), 421-425.

Labraga, J.C., Brandizi, L.D., López, M.A., 2011. Avances en el pronóstico climático de las anomalías de lluvia en la región pampeana. Meteorológica 36 (2), 59-71.

Liu, B., Coulthard, T.J., 2015. Mapping the interactions between rivers and sand dunes: implications for fluvial $\begin{array}{lllll}\text { and aeolian } & \text { geomorphology. } & \text { Geomorphology }\end{array}$ https://doi.org/10.1016/j.geomorph.2014.12.011

Maroulis, J.C., Nanson, G.C., Price, D.M., Pietsch, T., 2007. Aeolian-fluvial interaction and climate change: source-bordering dune development over the past $100 \mathrm{ka}$ on Cooper Creek, central Australia. Quaternary Science Reviews 26(3-4), 386-404. https://doi.org/10.1016/j.quascirev.2006.08.010

Mashimbye, Z.E., de Clercq, W.P., Van Niekerk, A., 2014. An evaluation of digital elevation models (DEMs) for delineating land components. Geoderma 213, 312-319. https://doi.org/10.1016/j.geoderma.2013.08.023 
McLaren, S. J., Al-Juaidi, F., Bateman, M.D., Millington, A. C., 2009. First evidence for episodic flooding events in the arid interior of central Saudi Arabia over the last $60 \mathrm{ka}$. Journal of Quaternary Science 24(2), 198207. https://doi.org/10.1002/jqs.1199

Mehl, A., Tripaldi, A., Zárate, M., 2018. Late Quaternary aeolian and fluvial-aeolian deposits from southwestern Pampas of Argentina, southern South America. Palaeogeography, Palaeoclimatology, Palaeoecology 511, 280-297. https://doi.org/10.1016/j.palaeo.2018.08.014

Meurisse, M., Van Vliet-Lanoë, B., Talon, B., Recourt, P., 2005. Holocene dune and peat complexes along the shore of northern France. Comptes Rendus Géoscience 337, 675-684.

Möller, M., Volk, M., Friedrich, K., Lymburner, L., 2008. Placing soil-genesis and transport processes into a landscape context: A multiscale terrain-analysis approach. Journal of Plant Nutrition and Soil Science 171(3), 419-430. https://doi.org/10.1002/jpln.200625039

NOAA, 2020. Historical El Nino/ La Nina episodes (1950-present). Available at: https://origin.cpc.ncep.noaa.gov/products/analysis_monitoring/ensostuff/ONI_v5.php (last access: 18/05/2020).

Odriozola, M.P., Contreras, F.I., 2016. Distribución de las lagunas de la Lomada Norte basada en una clasificación no supervisada de imágenes satelitales LANDSAT 5 TM. En: F.I. Contreras y M.P. Odriozola, M.P. (Comp). Libro de la Junta de Geografia de la Provincia de Corrientes, 23-32.

Perillo, G.M.E., 2001. Hacia una nomenclatura y clasificación de formas de fondo transversales formadas por flujos de agua. Revista de la Asociación Argentina de Sedimentología 8(2), 15-34.

Pye, K., Tsoar, H., 2009. Eolian sand and sand dunes. Springer, pp. 1-475.

Quirós, R., Drago, E. 1999. The environmental state of Argentinean lakes: an overview. Lakes and Reservoirs 4(12), 55-64. https://doi.org/10.1046/j.1440-1770.1999.00076.x.

Quirós, R., Rennella, A., Boveri, M., Rosso, J., Sosnovsky, A., 2002. Factores que afectan la estructura y el funcionamiento de las lagunas pampeanas. Ecología Austral 12, 175-185.

Saadouda, D., Hassanib, M., Peinadoc, F.J.M., Guettouchea, M. S., 2018. Application of fuzzy logic approach for wind erosion hazard mapping in Laghouat region (Algeria) using remote sensing and GIS. Aeolian Research 32, 24-34. https://doi.org/ 10.1016/j.aeolia.2018.01.002.

Sankey, J.B., Caster, J., Kasprak, A., East, A. E., 2018. The response of source-bordering aeolian dunefields to sediment-supply changes 2: Controlled floods of the Colorado River in Grand Canyon, Arizona, USA. Aeolian Research 32, 154-169. https://doi.org/10.1016/j.aeolia.2018.02.004

Scarpati, O.E., Forte Lay, J.A., Capriolo, A.D., 2008. La inundación del año 2001 en la provincia de Buenos Aires, Argentina. Mundo Agrario 9(17).

Sierra, M.E., Fernández Long, M.E., Bustos, C., 1994. Cronología de inundaciones y sequías en el noreste de la provincia de Buenos Aires 1911-89. Revista de la Facultad de Agronomía 14(3), 241-249.

Somlyody, L., Varis, O., 2006. Freshwater under pressure. International Review for Environmental Strategies. 6(2), 181-204.

Sosnovsky, A., Quirós, R., 2006. El estado trófico de pequeñas lagunas pampeanas, su relación con la hidrología y el uso de la tierra. Ecología Austral 16, 115-124.

Stanistreet, I.G., Stollhofen, H., 2002. Hoanib River flood deposits of Namib Desert interdunes asanalogues for thin permeability barrier mudstone layers in aeolianite reservoirs. Sedimentology 49(4), 719-736. https://doi.org/10.1046/j.1365-3091.2002.00458.x

Stutz, S., Tonello, M.S., González Sagrario, M.A., Navarro, D., Fontana, S.L., 2014. Historia ambiental de los lagos someros de la llanura Pampeana (Argentina) desde el Holoceno medio: Inferencias paleoclimáticas. Latin American Journal of Sedimentology and Basin Analysis 21, 119-138.

Taboada, M.A., Damiano, F., Lavado, R.S., 2009. Inundaciones en la Región Pampeana. Consecuencias sobre los suelos. Alteraciones de la fertilidad de los suelos: el halomorfismo, la acidez, el hidromorfismo y las inundaciones. EFA (Editorial Facultad de Agronomía), Universidad de Buenos Aires, Buenos Aires, pp $103-127$. 
Telfer, M.W., Fyfe, R.M., Lewin S., 2015. Automated mapping of linear dunefield morphometric parameters from remotely-sensed data. Aeolian Research 19, 215-224. https://doi.org/10.1016/j.aeolia.2015.03.001.

Thomas, D.S., Bailey, R. M., 2019. Analysis of late Quaternary dune field development in Asia using the accumulation intensity model. Aeolian Research 39, 33-46. https://doi.org/10.1016/j.aeolia.2019.04.005

Tripaldi, A., Forman, S.L., 2007. Geomorphology and chronology of Late Quaternary dune fields of western Argentina. Palaeogeography, Palaeoclimatology, Palaeoecology 251(2), 300-320. https://doi.org/10.1016/j.palaeo.2007.04.007

Tripaldi, A., Mehl, A., Zárate, M.A., 2018. Parabolic megadunes in a subtropical Quaternary inland dune field, southwestern Pampas, Argentina. Geomorphology, 321, 103-116. https://doi.org/10.1016/j.geomorph.2018.08.021

Tripaldi, A., Zárate, M.A., 2016. A review of Late Quaternary inland dune systems of South America east of the Andes. Quaternary International, 410, 96-110. https://doi.org/10.1016/j.quaint.2014.06.069

Tsoar, H., 2001. Types of aeolian sand dunes and their formation. In N. J. Balmforth and A. Provenzale (Ed.), Geomorphological fluid mechanics. Springer, Berlin, Heidelberg, pp. 403-429. https://doi.org/10.1007/3-540-45670-8_17

UCOFIN, 2012. Fondo fiduciario de infraestructura hídrica. Ministerio de Hacienda de la República Argentina.

Vicente-Serrano, S.M., Zouber, A., Lasanta, T., Pueyo, Y., 2012. Dryness is accelerating degradation of vulnerable shrublands in semiarid Mediterranean environments. Ecological Monographs 82, 407-428. https://doi.org/10.1890/11-2164.1

White, K., Bullard, J., Livingstone I., Moran L., 2015. A morphometric comparison of the Namib and southwest Kalahari dunefields using ASTER GDEM data. Aeolian Research, 19 (Part A), 87-95. https://doi.org/10.1016/j.aeolia.2015.09.006

Xu, Z., Lu, H., Yi, S., Vandenberghe, J., Mason, J. A., Zhou, Y., Wang, X., 2015. Climate-driven changes to dune activity during the Last Glacial Maximum and deglaciation in the Mu Us dune field, north-central China. Earth and Planetary Science Letters 427, 149-159. https://doi.org/10.1016/j.epsl.2015.07.002

Yan, N., Baas, A.C., 2017. Environmental controls, morphodynamic processes, and ecogeomorphic interactions of barchan to parabolic dune Parabolic dunes and their transformations under environmental and climatic changes: Towards a conceptual framework for understanding and prediction. Global and Planetary Change 124, 123-148. https://doi.org/10.1016/j.geomorph.2016.10.033

Yang, X., Liu T., Xiao, H., 2003. Evolution of megadunes and lakes in the Badain Jaran Desert, Inner Mongolia, China during the last 31,000 years. Quaternary International 104, 99-112. https://doi.org/10.1016/S10406182(02)00138-6

Yizhaq, H., Ashkenazy, Y., Tsoar, H., 2007. Why do active and stabilized dunes coexist under the same climatic conditions? Physical Review Letters, 98(18), 188001. https://doi.org/10.1103/PhysRevLett.98.188001

Zeng, L., Yi, S., Lu, H., Chen, Y., Lei, F., Xu, Z., Wang, X., Zhang, W., 2018. Response of dune mobility and pedogenesis to fluctuations in monsoon precipitation and human activity in the Hulunbuir dune field, northeastern China, since the last deglaciation. Global and Planetary Change, 168, 1-14. https://doi.org/10.1016/j.gloplacha.2018.06.001 